\title{
Pengenaan Pajak Pertambahan Nilai (PPN) Pada Transaksi E-Commerce
}

\author{
Muhammad Najib Ridho \\ Magister Ilmu Hukum, Universitas Indonesia \\ Email; mnridho07@gmail.com
}

\begin{abstract}
Abstrak. Penggunaan e-commerce setiap tahun semakin meningkat seiring dengan perkembangan teknologi yang semakin canggih dan memudahkan konsumen untuk memenuhi kebutuhannya. Ditambah dengan semakin banyak pilihan platform e-commerce sehingga mengubah pola belanja masyarakat ke arah online shopping. Setiap transaksi pada umumnya dikenakan Pajak Pertambahan Nilai (PPN), tak terkecuali transaksi secara online/e-commerce. Dalam penulisan ini akan dibahas ketentuan Pajak Pertambahan Nilai (PPN) yang dikenakan pada transaksi online/e-commerce Penulisan ini menggunakan metode penelitian yuridis normatif yang artinya bahan penelitian yang digunakan adalah data sekunder yang terdiri dari bahan-bahan hukum yang mengikat seperti ketentuan peraturan perundang-undangan, hasil karya penelitian hukum dan bahan pendukung lain seperti kamus. Penelitian ini akan menjelaskan bagaimana pengenaan Pajak Pertambahan Nilai (PPN) pada setiap transaksi secara online yang dilakukan sehingga masyakarat selaku produsen maupun konsumen dapat mengerti dan mampu menerapkannya.

Kata Kunci: e-commerce, transaksi, $P P N$

Abstract. The use of e-commerce is increasing every year along with the development of increasingly sophisticated technology and makes it easier for consumers to meet their needs. Coupled with the increasing choice of ecommerce platforms, it has changed people's shopping patterns towards online shopping. Every transaction is generally subject to Value Added Tax (VAT), including e-commerce transactions. In this paper will discuss the provisions of Value Added Tax (VAT) imposed on e-commerce. This writing uses a normative juridical research method, which means that the research material used is secondary data consisting of binding legal materials such as the provisions of laws and regulations. invitations, results of legal research works and other supporting materials such as dictionaries. This study will explain how the imposition of Value Added Tax (VAT) on every online transaction made so that the public as producers and consumers can understand and be able to apply it.
\end{abstract}

Keyword: e-commerce, transactions, VAT

\section{PENDAHULUAN}

Internet saat ini tidak hanya sebagai media informasi dan komunikasi, namun internet juga mampu menambah pendapatan seseorang dalam perekonomian. Selain menambah pendapatan seseorang, internet mampu memenuhi keinginan masyarakat dalam berbelanja secara praktis yaitu dengan adanya belanja online. Aktivitas transaksi jual beli secara online kian hari semakin bertambah seiring dengan perkembangan platformplatform penunjang yang mampu mempermudah konsumen dalam membeli barang yang diinginkan. Bagi sebagian orang, belanja online merupakan suatu kebutuhan yang harus dipenuhi untuk kehidupannya sebagai konsumen.

Kemudahan yang ditawarkan oleh kemajuan teknologi pada era globalisasi ini bukan tanpa risiko, kekurangan, dan kendala. Selain menghadapi permasalahan kejahatan dalam cyber space, juga memiliki permasalahan dalam bidang pajak. Pemerintah menghadapi tantangan tersendiri dalam menangani permasalahan pajak, khususnya pajak penghasilan dari e-commerce, karena kemajuan yang pesat di dunia usaha tidak selalu diikuti dengan kemajuan yang sama dalam bidang hukum. Hal ini karena electronic business mengembangkan proses bisnis yang baru, terlalu banyak informasi, tidak menggunakan kertas, bergerak dengan sangat cepat, dan harus ada pergeseran paradigma yang membutuhkan penerimaan, cara atau prosedur baru, pola pikir yang baru, dan ikuti juga dengan perkembangan ketentuan hukum atau regulasi. Begitu pula dengan kondisi Indonesia, salah satunya hingga saat ini pemerintah masih belum memiliki data pasti mengenai total transaksi secara keseluruhan mengenai belanja melalui internet, sehingga masih ada kesulitan untuk melakukan penghitungan jumlah pajak dan pengawasan dalam kegiatan e-commerce

Pesatnya perkembangan teknologi informasi dan komunikasi membuka peluang bisnis baru salah satunya adalah e-commerce. Perdagangan elektronik (e-commerce $=$ 
Jurnal Ilmu Sosial dan Pendidikan

http://ejournal.mandalanursa.org/index.php/JISIP/index

Terakreditasi Peringkat 5 (No. SK: 85/M/KPT/2020)

electronic commerce) adalah bagian dari $e$ lifestyle yang memungkinan transaksi jual beli dilakukan secara online dari mana pun dan kapan pun. E-commerce juga dapat diartikan sebagai suatu proses berbisnis dengan menggunakan teknologi elektronik yang menghubungkan antara perusahaan, konsumen, dan masyarakat dalam bentuk pertukaran atau penjualan barang, jasa, serta informasi secara elektronik. E-commerce berdasarkan Surat Edaran Direktur Jendral Pajak Nomor: SE-62/PJ/2013 tentang Penegasan Ketentuan Perpajakan atas transaksi e-commerce didefinisikan sebagai perdagangan barang dan/atau jasa yang dilakukan oleh pelaku usaha dan konsumen melalui sistem elektronik.

Awal mula toko online di Indonesia dimulai pada tahun 1994 saat Indosat menjadi internet service provider pertama di Indonesia sekaligus memberikan koneksi internet bagi seluruh masyrakat. Koneksi internet itu bisa dimanfaatkan sebagai jalan bagi kebanyakan orang untuk berjualan. Cikal bakal toko online baru muncul di tahun 1999 saat Andrew Darwis mendirikan sebuah forum bernama Kaskus yang juga menjadi forum jual beli. Selanjutnya, Bhinneka.com berdiri dan menjadi tempat jual beli juga di tanah air. Pada akhirnya, muncul berbagai macam toko online (e-commerce) baik yang berasal dari dalam negeri seperti Bukalapak dan Tokopedia hingga yang berasal dari luar negeri seperti Lazada dan Shopee membuat konsumen memiliki banyak pilihan dalam menentukan tempat beli yang diinginkan.

Di tahun 2014, Tokopedia mencetak sejarah dengan mendapatkan kucuran dana sebesar US\$ 100 juta dan menjadi yang terbesar dalam sejarah e-commerce. Namun, rekor ini dikalahkan juga oleh Tokopedia pada tahun 2017. Dalam sejarahnya, ada banyak pemain baru atau lama yang berseliweran di dunia e-commerce Indonesia. Di tahun 2015, Tokobagus dan Berniaga memutuskan untuk melebur menjadi satu dibawah nama OLX yang berfokus pada jual beli barang second. Hingga kini, sudah tidak terhitung ada berapa banyak e-commerce atau layanan uang
Vol. 5. No. 1 Januari 2021

p-ISSN: 2598-9944 e- ISSN: 2656-6753

elektronik yang muncul. Pertumbuhan mereka diprediksi akan terus bertumbuh hingga angka yang sangat tinggi sehingga mendukung bertumbuhnya ekosistem ekonomi digital di Indonesia.

Pada tahun 2018, Badan Pusat Statistik mencatkan terdapat 24.82 juta transaksi melalui e-commerce di Indonesia. Transaksi tersebut berasal dari 13.485 usaha e-commerce dengan nilai transaksi mencapai 17.21 triliun rupiah. Pada tahun 2019, aktivitas transaksi $e$ commerce sendiri tidak dapat dipandang sebelah mata. Nilai transaksi yang dihasilkan pada masing-masing provinsi pun dinilai cukup menambah perekonomian daerah.

Ditinjau dari peraturan perundangundangan perpajakan, semestinya perdagangan secara online sangat berpotensi untuk dikenakan Pajak. Tetapi karena kurangnya pengaturan mengenai pengenaan pajak terhadap bisnis online dapat menimbulkan adanya kekosongan norma yang terjadi dalam peraturan perpajakan di Indonesia. Sehingga potensi perpajakan tidak dimanfaatkan secara efektif. Seharusnya ini menjadi potensi penerimaan pajak bagi pemerintah karena bagaimanapun, transaksi jual-beli secara online juga merupakan objek pajak. Adapun salah satu jenis pajak yang dapat dikenakan dalam transaksi jual-beli online ini adalah Pajak Pertambahan Nilai (PPN). Oleh karena itu, dalam penulisan ini akan dibahas mengenai definisi e-commerce di Indonesia dengan dikaitkan sebagai salah satu objek Pajak Pertambahan Nilai (PPN) dan bagaimana pengenaan Pajak Pertambahan Nilai (PPN) dalam transaksi jual beli online ( $e$ commerce).

\section{METODE PENELITIAN}

Penulis dalam menyusun penelitian ini menggunakan metode penelitian yuridis normatif. Dalam penelitian yuridis normatif, data-data yang digunakan sebagai bahan penelitian adalah data sekunder yang mencakup:

1. Bahan hukum primer, yaitu bahan-bahan hukum yang mengikat dan terdiri dari:

a. Norma (dasar) atau kaidah dasar;

b. Peraturan Dasar; 
c. Peraturan Perundang-undangan;

d. Bahan hukum yang tidak dikodifikasikan;

e. Yurisprudensi;

f. Traktat; dan

g. Bahan hukum lain dari zaman penjajahan yang hingga kini masih berlaku.

2. Bahan hukum sekunder, yang memberikan penjelasan mengenai bahan hukum primer, seperti rancangan undangundang, hasil penelitian, hasil karya dari kalangan hukum dan seterusnya.

3. Bahan hukum tertier, yakni bahan yang memberikan petunjuk maupun penjelasan terhadap bahan hukum primer dan sekunder, contohnya kamus.

Metode penelitian hukum normatif juga disebut metode penelitian hukum doktriner atau penelitian perpustakaan. Dinamakan penelitian hukum doktrinet dikarenakan penelitian ini hanya ditujukan pada nilai, norma dan peraturan-peraturan tertulis sehingga penelitian ini sangat erat hubungannya pada perpustakaan karena akan membutuhkan data-data yang bersifat sekunder pada perpustakaan.

\section{HASIL DAN PEMBAHASAN}

\section{A. Definisi E-Commerce}

Secara definisi, perdagangan pada umumnya adalah tatanan kegiatan yang terkait dengan transaksi barang dan/atau jasa di dalam negeri dan melampaui batas wilayah negara dengan tujuan pengalihan hak atas barang dan/atau jasa untuk memperoieh imbalan atau kompensasi. Perdagangan elektronik yang disebut e-commerce adalah penggunaan jaringan komunikasi dan komputer untuk melaksanakan proses bisnis. pandangan popular dari e-commerce adalah penggunaan internet dan komputer dengan browser web untuk membeli atau menjuaal produk. Sebenarnya e-commerce adalah bisnis dari yang dilakukan antar bisnis bukan kepada konsumen, namun perkembangan yang terjadi menimbulkan e-commerce bisnis ke konsumen.

Menurut Kalakota dan Winston, definisi e-commerce dapat ditinjau dari beberapa perspektif, yaitu:

1. Dari perspektif komunikasi, e-commerce adalah pengiriman barang, layanan, informasi, atau pembayaran melalui jaringan komputer atau melalui peralatan elektronik lainnya.

2. Dari perspektif proses bisnis, e-commerce adalah aplikasi dari teknologi yang menuju otomatisasi dari transaksi bisnis dan aliran kerja.

3. Dari perspektif layanan, e-commerce merupakan suatu alat yang memenuhi keinginan perusahaan, konsumen, dan manajemen untuk memangkas biaya layanan (service cost) Ketika meningkatkan kualitas barang dan meningkatkan kecepatan layanan pengiriman.

4. Dari perspektif online, e-commerce menyediakan kemampuan untuk membeli dan menjual barang ataupun informasi melalui internet dan sarana online lainnya.

Perdagangan e-commerce adalah bagian dari e-lifestyle yang memungkinkan transaksi jual beli dilakukan secara online dari sudut tempat mana pun. Adam, D. V., \& Astin, I. P. menyatakan klasifikasi e commerce yang paling banyak digunakan di Indonesia adalah Business to Business (B2B) dan Business to Customers (B2C). Menurut peraturan Surat Edaran Direktur Jenderal Pajak Nomor$62 / \mathrm{PJ} / 2013$ di Indonesia bentuk e-commerce terbagi menjadi empat bagian yaitu antara lain:

1. Classified Ads adalah situs iklan baris, dimana situs yang bersangkutan tidak memfasilitasi kegiatan transaksi online.

2. Market Place adalah model bisnis dimana website yang bersangkutan tidak hanya membantu mempromosikan barang dagangan saja, tapi juga memfasilitasi transaksi uang secara onliine untuk para pedagang online.

3. Retail Online adalah toko online dengan alamat website (domain) sendiri dimana penjual memiliki stok produk/jasa dan menjualnya secara online kepada pembeli.

4. Daily Deals adalah kegiatan menyediakan tempat kegiatan usaha berupa Daily Deals 
sebagai tempat Daily Deals Merchant menjual barang/jasa kepada pembeli dengan menggunakan voucher sebagai cara pembayaran.

Keberadaan e-commerce di Indonesia tentu memiliki dampak positif tersendiri. Selain membantu perekonomian secara umum, $e$-commerce memiliki beberapa manfaat, baik itu organisasi, perusahaan dan masyarakat itu sendiri. Berikut beberapa manfaat dari $e$ commerce:

1. Bagi organisasi pemilik e-commerce:

a. Memperluas market place hingga kepasar nasional dan internasional.

b. Dengan capital outplay yang minim, sebuah perusahaaan dapat dengan mudah menemukan lebih banyak pelanggan, supplier yang lebih baik dan partner bisnis yang paling cocok dari seluruh dunia.

c. E-commerce menurunkan biaya pembuatan, pemrosesan, pendistribusian, penyimpanan, dan pencarian informasi yang menggunakan kertas.

d. E-commerce mengurangi waktu antara outlay modal dan penerimaan produk dan jasa.

2. Bagi konsumen:

a. E-commerce memungkinkan pelanggan untuk berbelanja atau melakukan transaksi selama 24 jam sehari sepanjang tahun dari hampir setiap lokasi.

b. E-commerce memberikan lebih banyak pilihan kepada pelanggan, mereka bisa memilih berbagai produk dari banyak vendor.

c. E-commerce menyediakan produk dan jasa yang tidak mahal kepada pelanggan dengan cara mengunjungi banyak tempat dan melakukan perbandingan secara cepat.

d. Pelanggan bisa menerima informasi yang relevan secara detil dalam hitungan detik, bukan lagi hari atau minggu.

3. Bagi Masyarakat

a. E-commerce memungkinkan orang untuk bekerja didalam rumah dan tidak harus keluar rumah untuk berbelanja. Ini berakibat menurunkan arus kepadatan lalu lintas di jalan serta mengurangi polusi udara.

b. E-commerce memungkinkan orang di negara-negara dunia ketiga dan wilayah pedesaan untuk menikmati aneka produk dan jasa yang akan susah mereka dapatkan tanpa $e$ commerce.

Dalam perkembangannya, merebaknya transaksi e-commerce sendiri menjadikan transaksi jual-beli online menjadi salah satu objek Pajak Pertambahan Nilai (PPN). Transaksi e-commerce secara umum sebenarnya sama dengan transaksi yang dilakukan secara konvensional, sehingga untuk memenuhi asas keadilan, transaksi ini pun tak luput dari pengenaan Pajak Pertambahan Nilai (PPN). Berikut gambaran pemikiran penerapan kebijakannya di Indonesia:

\section{Tabel 1. Kerangka Pemikiran Penerapan} Kebijakan Pajak Pertambahan Nilai Atas Transaksi E-Commerce

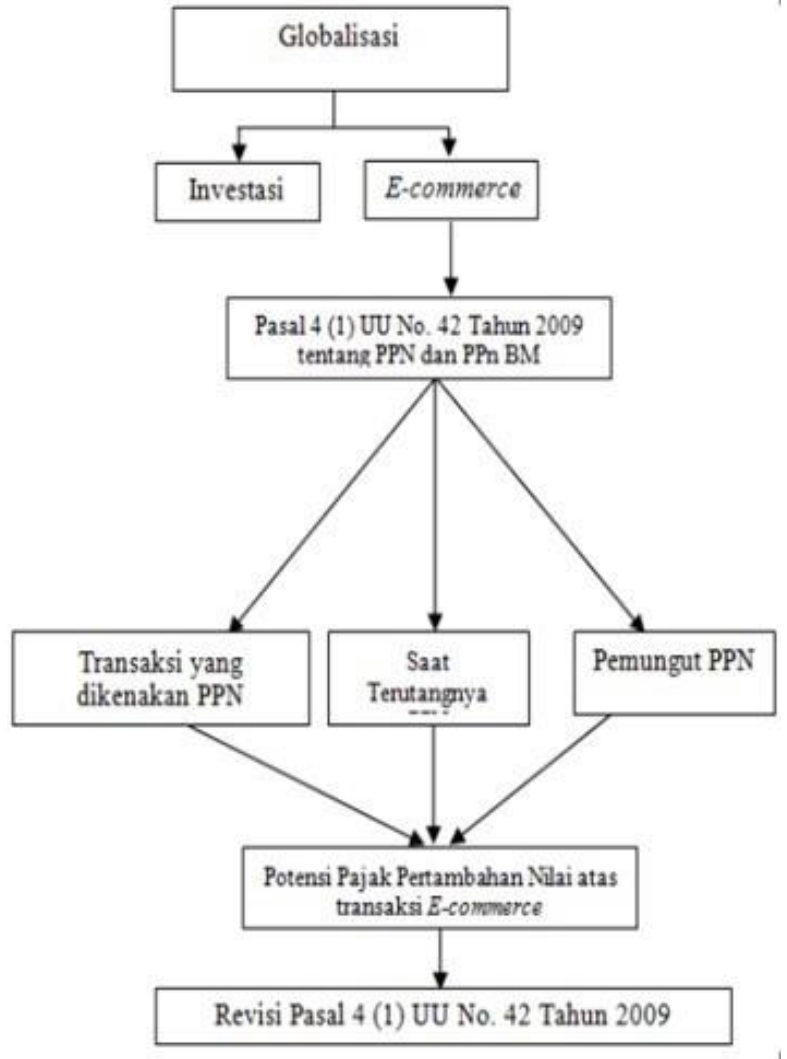




\section{B. Pengenaan Pajak Pertambahan Nilai (PPN) Atas Transaksi Jual Beli Melalui Platform E-Commerce}

Pajak merupakan kontribusi utama pemasukan pemerintah, dan pajak juga merupakan sumber belanja negara. Ada dua fungsi pajak yaitu fungsi budgeter dan fungsi regulerend. Pertama; berfungsi sebagai budgeter, yaitu pajak sebagai sumber dana pemerintah untuk membiayai pengeluaran-pengeluarannya. Fungsi pajak budgeter adalah fungsi yang letaknya disektor publik, dan pajak tersebut erupakan suatu alat untuk memasukkan uang sebanyak-banyaknya ke dalam kas negara yang pada waktunya akan digunakan untuk membiayai pengeluaran-pengeluaran negara, terutama untuk membiayai pengeluaran rutin, dan apabila setelah itu masih ada sisa (surplus), maka surplus ini dapat digunakan untuk membiayai investasi pemerintah (public saving untuk public invesment).

Kedua; berfungsi sebagai Regulerend atau mengatur yaitu pajak sebagai alat untuk mengatur atau melaksanakan kebijakan pemerintah dalam bidang sosial dan ekonomi. Pajak mempunyai fungsi mengatur (Regulerend), dalam arti bahwa pajak itu dapat digunakan sebagai alat untuk mengatur atau melaksanakan kebijaksanaan Negara dalam lapangan ekonomi dan sosial dengan fungsi mengaturnya pajak digunakan sebagai suatu alat untuk mencapai tujuan-tujuan tertentu yang letaknya diluar bidang Keuangan dan fungsi mengatur itu banyak ditujukan terhadap sektor swasta. Misalnya dalam pajak perseroan salah satu pasal dari ordonansi pajak perseroan 1925 memberi kebebasan dari pajak perseroan atas pengenaan tarif yang rendah terhadapbadan badan koperasi yang berkedudukan di Indonesia.

Salah satu jenis pajak pusat yang dibebankan kepada masyarakat adalah Pajak Pertambahan Nilai (PPN). Pajak Pertambahan Nilai (PPN) adalah pajak atas konsumsi barang dan jasa di daerah pabean yang dikenakan secara bertingkat di setiap jalur produksi dan distribusi. Pengenaan Pajak Pertambahan Nilai sangat dipengaruhi oleh perkembangan transaksi bisnis serta pola konsumsi masyarakat yang merupakan objek dari Pajak Pertambahan Nilai. Perkembangan ekonomi yang sangat dinamis baik di tingkat nasional, regional, maupun internasional terus menciptakan jenis serta pola transaksi bisnis yang baru. Sebagai contoh di bidang jasa, banyak timbul transaksi jasa baru atau modifikasi dari transaksi sebelumnya yang pengenaan Pajak Pertambahan Nilainya belum diatur dalam Undang-Undang Pajak Pertambahan Nilai.

Untuk menentukan apa-apa saja yang merupakan objek dari Pajak Pertambahan Nilai (PPN) dapat dilihat dalam ketentuan Pasal 4 Undang-Undang Nomor 42 Tahun 2009 tentang Perubahan Atas Undang-Undang Nomor 8 Tahun 1983 tentang Pajak Pertambahan Nilai Barang dan Jasa dan Pajak Penjualan atas Barang Mewah, yakni sebagai berikut:

a. Penyerahan Barang Kena Pajak (BKP) dan Jasa Kena Pajak (JKP) di dalam Daerah Pabean yang dilakukan oleh pengusaha;

b. Impor Barang Kena Pajak;

c. Pemanfaatan Barang Kena Pajak tidak berwujud dari luar Daerah Pabean di dalam Daerah Pabean;

d. Pemanfaatan Jasa Kena Pajak dari luar Daerah Pabean di dalam Daerah Pabean;

e. Ekspor Barang Kena Pajak berwujud atau tidak berwujud dan Ekspor Jasa Kena Pajak oleh Pengusaha Kena Pajak (PKP);

f. Ekspor Jasa Kena Pajak berwujud atau tidak berwujud dan Ekspor Jasa Kena Pajak oleh Pengusaha Kena Pajak (PKP);

Sebagaimana dijelaskan di dalam penegasan peraturan perpajakan SE 62/PJ/2013 atas e-commerce, Perkembangan teknologi informasi dan komunikasi telah menyebabkan transformasi model dan strategi bisnis yang perlu ditegaskan aspek perpajakannya. Pada prinsipnya, transaksi perdagangan barang dan/atau jasa melalui sistem elektronik, yang selanjutnya disebut $e$ commerce sama dengan transaksi perdagangan barang dan/atau jasa lainnya, tetapi berbeda dalam hal cara atau alat yang digunakan. Oleh karena itu, tidak ada perbedaan perlakuan perpajakan antara transaksi e-commerce dan 
Jurnal Ilmu Sosial dan Pendidikan

http://ejournal.mandalanursa.org/index.php/JISIP/index

Terakreditasi Peringkat 5 (No. SK: 85/M/KPT/2020)

transaksi perdagangan barang dan/atau jasa lainnya.

Dalam mekanisme pemungutannya, Pajak Pertambahan Nilai (PPN) mengenal dua prinsip pemungutan, yaitu prinsip tempat asal (origin principle) dan prinsip tempat tujuan (destination principle). Prinsip tempat asal mengandung pengertian bahwa Pajak Pertambahan Nilai dipungut di tempat asal barang atau jasa yang akan dikonsumsi. Sedangkan berdasarkan prinsip tempat tujuan, Pajak Pertambahan Nilai dipungut di tempat barang atau jasa dikonsumsi. Kedua prinsip ini sangat besar pengaruhnya terhadap kedudukan Pajak Pertambahan Nilai dalam perdagangan internasional. Apabila dikehendaki ada sifat netral Pajak Pertambahan Nilai (PPN) di bidang perdagangan internasional, maka prinsip yang dianut adalah prinsip tempat tujuan (destination principle). Dalam prinsip ini, komoditi impor akan menanggung beban pajak yang sama dengan barang produksi dalam negeri, apabila komoditi tersebut dikonsumsi di dalam negeri.

Untuk mengetahui proses pengenaan Pajak Pertambahan Nilai (PPN) dalam transaksi e-commerce ini maka dapat merujuk pada Surat Edaran Direktur Jenderal Pajak Nomor SE-62/PJ/2013. Untuk menentukan saat dan tempat terutang Pajak Pertambahan Nilai (PPN) dalam Surat Edaran ini yakni sebagai berikut:

1. Terutangnya Pajak Pertambahan Nilai (PPN) terjadi saat:

a. Penyerahan Barang Kena Pajak dan/atau penyerahan Jasa Kena Pajak;

b. Impor Barang Kena Pajak;

c. Pemanfaatan Barang Kena Pajak Tidak Berwujud dan/atau pemanfaatan Jasa Kena Pajak dari luar Daerah Pabean;

d. Ekspor Barang Kena Pajak Berwujud, ekspor Barang Kena Pajak Tidak Berwujud, dan/atau ekspor Jasa Kena Pajak; atau

e. Pembayaran, dalam hal pembayaran diterima sebelum penyerahan Barang Kena Pajak atau sebelum penyerahan Jasa Kena Pajak atau dalam hal pembayaran dilakukan sebelum
Vol. 5. No. 1 Januari 2021

p-ISSN: 2598-9944 e-ISSN: 2656-6753

dimulainya pemanfaatan Barang Kena Pajak Tidak Berwujud atau Jasa Kena Pajak dari luar Daerah Pabean.

2. Tempat Pajak Pertambahan Nilai terutang:

a. Pengusaha Kena Pajak yang melakukan penyerahan sebagaimana dimaksud dalam Pasal 4 ayat (1) huruf a, huruf $\mathrm{c}$, huruf $\mathrm{f}$, huruf $\mathrm{g}$, dan/atau huruf $h$ Undang-Undang Pajak Pertambahan Nilai terutang pajak di tempat tinggal atau tempat kedudukan dan/atau tempat kegiatan usaha dilakukan atau tempat lain selain tempat tinggal atau tempat kedudukan dan/atau tempat kegiatan usaha

dilakukan yang diatur dengan Peraturan Direktur Jenderal Pajak.

b. Dalam hal impor, terutangnya pajak terjadi di tempat Barang Kena Pajak dimasukkan dan dipungut melalui Direktorat Jenderal Bea dan Cukai.

c. Orang pribadi atau badan yang memanfaatkan Barang Kena Pajak tidak berwujud dan/atau Jasa Kena Pajak dari luar Daerah Pabean di dalam Daerah Pabean sebagaimana dimaksud dalam Pasal 4 ayat (1) huruf d dan huruf e Undang-Undang Pajak Pertambahan Nilai terutang pajak di tempat tinggal atau tempat kedudukan dan/atau tempat kegiatan usaha.

Prinsip-prinsip perpajakan atas $e$ commerce adalah Neutrality,Perpajakan seharusnya menjadi netral dan adil dalam membedakan antara bentuk transaksi $e$ commerce dengan bentuk transaksi konvensional. Keputusan bisnis seharusnya dimotivasi oleh keadaan ekonomi dibandingkan dengan pertimbangan pajak. Wajib pajak dalam situasi dan transaksi yang sama seharusnya menjadi subjek yang sama pula dalam level perpajakan. Efficiency, Compliance cost untuk Wajib Pajak dan Administrative Cost bagi pejabat pajak seharusnya dapat diminimalkan sejauh mungkin.

Di Indonesia sendiri pemungutan pajak menggunakan Sistem Self Assesment dimana 
Jurnal Ilmu Sosial dan Pendidikan

http://ejournal.mandalanursa.org/index.php/JISIP/index

Terakreditasi Peringkat 5 (No. SK: 85/M/KPT/2020)

wajib pajak sendiri yang menghitung dan menilai pemenuhan kewajiban perpajakannya. Hal ini menimbulkan ketidakefektifan pemungutan pajak penghasilan yang adil bagi setiap pihak di Indonesia. Seharusnya pemerintah membuat aturan yang secara khusus mengatur mengenai pengenaan PPN bagi transaksi e-commerce dan juga bagi transaksi secara konvensional, sehingga keadilan bagi seluruh masyarakat Indonesia dapat tercipta. Faktor Penegak hukum juga memegang peranan penting dalam hal ini. Penegak hukum harus tegas dan melakukan pengawasan secara berkala sehingga tidak ada celah bagi wajib pajak untuk lalai dalam kewajibannya membayar pajak sesuai dengan ketentuan perpajakan di Indonesia.

Seperti misalnya pada e-commerce Bukalapak, Divisi Pajak PT Bukalapak.com mengatakan bahwa perusahaan tidak melakukan penerapan atau ketentuan khusus bagi pengguna aplikasi Bukalapak, hal tersebut mengacu pada sistem perpajakan yang dilakukan di Indonesia yaitu self assessment. Dalam sistem tersebut wajib pajak diberi wewenang oleh otoritas pajak untuk menghitung, membayar dan melapor sendiri atas kewajiban perpajakannya. Pada SE$62 / \mathrm{PJ} / 2013$ juga menyatakan penerapan ketentuan perpajakan atas transaksi $e$ commerce sama dengan ketentuan perpajakan umumnya. Oleh karena itu Bukalapak tidak memberikan ketentuan atau syarat khusus, termasuk terhadap Warga Negara Asing yang berjualan dalam aplikasi Bukalapak.

Masyarakat sebagai wajib pajak sebaiknya diberikan edukasi mengenai pentingnya membayar pajak bagi suatu negara dan diberi arahan yang baik dan benar mengenai tata cara membayar pajak, sehingga diharapkan masyarakat dapat sadar dan membayar pajak tepat waktu serta sesuai dengan ketentuan perpajakan. Sehingga sistem self assesment di Indonesia dapat berjalan dengan efektif. Pemerintah pun sebaiknya tetap terbuka dan dapat memberikan manfaat yang sebanding terhadap pembangunan negara dan jika memungkinkan dapat mewajibkan tiap pelaku usaha online untuk memiliki Izin Usaha online dan didaftarkan sehingga dapat
Vol. 5. No. 1 Januari 2021

p-ISSN: 2598-9944 e-ISSN: 2656-6753

memudahkan dalam pengawasan serta pengenaan pajak terhadap pelaku e-commerce di Indonesia.

\section{KESIMPULAN}

Berdasarkan pembahasan pada bab sebelumnya, maka dapat ditarik kesimpulan dalam penulisan ini, yakni sebagai berikut:

1. Perdagangan elektronik yang disebut $e$ commerce adalah penggunaan jaringan komunikasi dan komputer untuk melaksanakan proses bisnis. pandangan popular dari e-commerce adalah penggunaan internet dan komputer dengan browser web untuk membeli atau menjuaal produk. Merebaknya transaksi e-commerce sendiri menjadikan transaksi jual-beli online menjadi salah satu objek Pajak Pertambahan Nilai (PPN).

2. Mekanisme pemungutan Pajak Pertambahan Nilai (PPN) mengenal dua prinsip pemungutan, yaitu prinsip tempat asal (origin principle) dan prinsip tempat tujuan (destination principle). Prinsip tempat asal mengandung pengertian bahwa Pajak Pertambahan Nilai dipungut di tempat asal barang atau jasa yang akan dikonsumsi. Sedangkan berdasarkan prinsip tempat tujuan, Pajak Pertambahan Nilai dipungut di tempat barang atau jasa dikonsumsi.

\section{SARAN}

Ketentuan pengenaan PPN terhadap pelaku e-commerce sebaiknya dibuatkan pengarahan lebih masif kepada masyarakat, mengingat penggunaan e-commerce sendiri hampir dilakukan oleh seluruh masyarakat. Hal ini dimaksudkan agar seluruh lapisan masyakarat mengerti bahwa ada kewajiban pajak dalam setiap transaksi online yang dilakukan mereka.

Pengarahan ini dapat dilakukan oleh pemerintah c.q. Kementerian Keuangan c.q. Direktorat Jenderal Pajak dengan menggandeng beberapa platform e-commerce besar untuk diedukasi. Selanjutnya platformplatform inilah nanti akan mengedukasi merchant-merchant nya secara bertahap. 


\section{DAFTAR PUSTAKA}

Devany, Sony. 2006. Perpajakan: Konsep, Teori, dan Isu. Jakarta: Kencana

Indonesia. Peraturan Pemerintah RI No. 83 Tahun 2019 tentang Penyediaan Tenaga Teknis yang Kompeten di Bidang Perdagangan Jasa. LNRI No. 233 Tahun 2019

Kementerian Keuangan, Surat Edaran Direktur Jenderal Pajak Nomor SE-62/PJ/2013 tentang Penegasan Ketentuan Perpajakan Atas Transasi ECommerce

Leonardo, Posma dan Christine Tjen. 2020. Penerapan Ketentuan Perpajakan pada Transaksi E-Commerce pada Platform Marketplace. Jurnal Pendidikan Akuntansi dan Keuangan Vo. 8, No. 1

McLeod, Raymond and Jr. George P. Schell. 2007. Management Information System, New Jersey: Pearson Education, Inc

Mulya, Ali Sandy dan Syaron Vania Agatha. 2020. Apakah Pajak Pertambahan Nilai Atas E-Commerce Dapat Diterapkan Di Indonesia?, Journal of Accounting Scinence and Technology Vol 1, No. 1

ndonesia, Undang-Undang tentang Pajak Pertambahan Nilai Barang dan Jasa dan Pajak Penjualan atas Barang Mewah, Undang- Undang No 8 Tahun 1983 sebagaimana telah diubah dengan UU No 42 Tahun 2009 LNRI Tahun 2009 Nomor 150

Nugraha, Daniel. 2019. Toko Online di Indonesia, Sejarah dan Pengaruhnya. Paper Blog 24. https://www.paper.id/blog/headline/t oko-online-di-indonesia/, diakses pada tanggal 15 Desember 2020

Rijadi, Muchlisin. Perdagangan Elektronik. https://www.kajianpustaka.com/ 2013/04/perdagangan-elektronik-ecommerce.html, diakses pada tanggal 15 Desember 2020

S, Munawir. 1985. Pokok-Pokok Perpajakan. Yogyakarta: Liberty
Sakti, Nufransa Wira. 2014. Seminar Perpajakan Pemenuhan Kewajiban Perpajakan Bagi Pelaku E-Commerce di Indonesia.

Sasana, Lodang Prananta Widya. 2019. Analisis Penerapan Kebijakan Pajak Pertambahan Nilai Atas Transaksi ECommerce Pada Direktorat Jenderal Pajak. Jurnal Mandiri: Ilmu Pengetahuan, Seni dan Teknologi Vol 3 No. 1 Lembaga Kajian Demokrasi dan Pemberdayaan Masyarakat (LKD-PM), h. 50-66

Soekanto, Soerjono dan Sri Mamudji, Penelitian Hukum Normatif Suatu Tinjauan Singkat, (Jakarta: Rajagrafindo Persada, 2012).

Sub Direktorat Statistik Komunikasi dan Teknologi Informasi. 2019. Statistik E-Commerce 2019. Badan Pusat Statistik, Jakarta, h. 22, https://www.bps.go.id/publication/20 19/12/18/fd1e96b05342e479a83917c 6/statistik-e-commerce-2019.html, diakses pada tanggal 15 Desember 2020

Suteki dan Galang Taufani, Metodologi Penelitian Hukum (Filsafat, Teori dan Praktik), (Depok: Rajagrafindo Persada, 2020).

Suyanto, M. 2003. Strategi Periklanan Pada ECommerce Perusahaan Top Dunia, Yogyakarta: Andi 